\title{
Analisis Strategi Pemasaran Pada PT. Central International Education
}

\author{
Tri Veny Pitri \& Muji Gunarto \\ Universitas Bina Darma \\ Email: triveny01@gmail.com,mgunarto@binadarma.ac.id
}

\begin{abstract}
The aim of this study was to decide the marketing strategy of PT. Central International Education by using SWOT analysis, so it could be conclude that there were some internal factors that had stength such as cleanliness, a large parking area, good and reliable services, and products with good quality. meanwhile, there were some weaknesses such complains handling which was still not maximum, less promotion strategies and employees coming late to the office. some external factors were marketing opportunities, target market, product quality and good relationship with customers. there were also some threats such as business competitor s, government rule and new competitors. some strategies that can be used in future are giving good and quick responses to customers, improving promotion strategies, improving company services to ensure the cumtomers, maximizing promotion and advertisments to attract the customers and extending the market regions.
\end{abstract}

Keywords: marketing strategy, SWOT analysis

\section{Pendahuluan}

Perusahaan yang bergerak di bidang produk ataupun jasa, perusahaan mempunyai tujuan untuk tetap berkembang. Dimana dapat dilihat dari tumbuhnya perusahaan dengan jasa yang sama sebagai pesaing, sehingga akan terjadi persaingan dalam memperebutkan pangsa pasar dan pelanggan. Strategi Pemasaran berorientasi menciptakan nilai tambah bagi pelanggan dan membangun hubungan relationship dengan pelanggan dan memahami kebutuhan pasar yang meliputi keinginan pelanggan, menata informasi pemasaran dan data pelanggan, membangun hubungan yang saling menguntungkan dalam menciptakan kepuasan pelanggan. (Rinaldi, 2015).

PT. Central International Education merupakan jaringan sekolah bahasa yang menyediakan jasa pelatihan dan kursus bahasa Inggris. Sejak berdiri pada tahun 2007. PT. Central International Education menyediakan beragam kursus bahasa Inggris bagi kelompok usia yang berbeda - beda mulai dari anak - anak, remaja, hingga dewasa. PT. Central International Education juga memiliki 9 cabang kursus bahasa Inggris di Indonesia, termasuk kota Palembang. Kantor pusat PT. Central International Education Palembang berlokasi di Jalan bangau. Kantor pusat PT. Central International Education Palembang ini memiliki beberapa cabang kursus (center) yang berlokasi di Batam, Jakarta, Lampung, Solo, Pontianak, Jambi, Medan, Pangkal Pinang dan Yogyakarta. Dengan beragamnya lokasi center PT. Central International Education, masyarakat dapat memilih lokasi kursus yang sesuai dengan yang diinginkan. 


\section{Literature Review}

Menurut Hasan (2013), strategi pemasaran yang baik harus dibangun atas dasar pemahaman bisnis yang kuat, dikombinasikan dengan pemahaman kebutuhan dan keinginan pelanggan, pesaing dan skills, dan core bisnis termasuk dengan para pemasok dan distributor. Sedangkan menurut Assauri (2013), menyatakan Strategi pemasaran adalah serangkaian tujuan dan sasaran, kebijakan dan aturan yang memberi arah kepada usaha-usaha pemasaran perusahaan dari waktu ke waktu, pada masing-masing tingkatan dan acuan serta alokasinya, terutama sebagai tanggapan perusahaan dalam menghadapi lingkungan dan keadaan persaingan yang selalu berubah.

Adapun pengertian 7P menurut Kotler dan Amstrong (2012), dapat disimpulkan bauran pemasaran jasa yaitu product, price, place, promotion, people, physical evidence, and process.

\section{Product}

Produk adalah mengelola unsur produk termasuk perencanaan dan pengembangan produk atau jasa yang tepat untuk dipasarkan dengan mengubah produk atau jasa yang ada dengan menambah dan mengambil tindakan yang lain yang mempengaruhi bermacam-macam produk atau jasa.

2. Price

adalah suatu sistem manajemen perusahaan yang akan menentukan harga dasar yang tepat bagi produk atau jasa dan harus menentukan strategi yang menyangkut potongan harga, pembayaran ongkos angkut dan berbagi variabel yang bersangkutan.

3. Place

Distribusi yakni memilih dan mengelola saluran perdagangan yang dipakai untuk menyalurkan produk atau jasa dan juga untuk melayani pasar sasaran, serta mengembangkan sistem distribusi untuk pengiriman dan perniagaan produk secara fisik.

4. Promotion

Promosi adalah suatu unsur yang digunakan untuk memberitahukan dan membujuk pasar tentang produk atau jasa yang baru pada perusahaan melalui iklan, penjualan pribadi, promosi penjualan, maupun publikasi.

5. Physical Evidence

Sarana fisik merupakan hal nyata yang turut mempengaruhi keputusan konsumen untuk membeli dan menggunakan produk atau jasa yang ditawarkan. Unsur yang termasuk dalam sarana fisik antara lain lingkungan atau bangunan fisik, peralatan, perlengkapan, logo, warna dan barang-barang lainnya.

6. People

Orang adalah semua pelaku yang memainkan peranan penting dalam penyajian jasa sehingga dapat mempengaruhi persepsi pembeli. Elemen dari orang adalah pegawai perusahaan, konsumen, dan konsumen lain. Semua sikap dan tindakan karyawan, cara berpakaian karyawan dan penampilan karyawan memiliki pengaruh terhadap keberhasilan penyampaian jasa.

7. Process

Proses adalah semua prosedur aktual, mekanisme, dan aliran aktivitas yang digunakan untuk menyampaikan jasa. Elemen proses ini memiliki arti sesuatu untuk 
menyampaikan jasa. Proses dalam jasa merupakan faktor utama dalam bauran pemasaran jasa seperti pelanggan jasa akan senang merasakan sistem penyerahan jasa sebagai bagian jasa itu sendiri.

\section{Metode Penelitian}

Metode yang digunakan dalam penelitian ini adalah metode deskriptif dan verifikatif dengan pendekatan kuantitatif. Metode ini mengumpulkan data yang diperoleh dari karyawan Central kemudian mengolah data secara saksama mengenai aspek-aspek tertentu yang berkaitan dengan masalah yang sedang diteliti sehingga akan memperoleh data-data yang dapat mendukung penyusunan laporan penelitian. Data-data yang diperoleh tersebut kemudian diproses dan dianalisis lebih lanjut dengan dasar teori yang telah dipelajari sehingga memperoleh gambaran mengenai objek tersebut dan dapat ditarik kesimpulan mengenai masalah yang diteliti.

Teknik pengumpulan data adalah observasi, wawancara dan dokumentasi. Peneliti melakukan pengumpulan data dengan mengadakan pengamatan langsung pada objek penelitian untuk memperoleh data yang di perlukan. Dalam hal ini peneliti langsung mengamati keadaan perusahaan. Wawancara melakukan metode pengumpulan data yang didasarkan percakapan secara intensif dengan berlandaskan pada tujuan penelitian. Dokumentasi melakukan dengan jalan mengumpulkan dokumen-dokumen perusahaan yang berhubungan dalam penelitian ini.

Teknik analisis yang dipakai menggunakan analisis SWOT (strengths, weaknesses, opportunities and threats) yang didasarkan pada logika dan digunakan untuk menetapkan strategi dan suatu teknik yang dirancang khusus untuk membantu strategi pemasaran yang harus dijalankan oleh perusahaan. Analisis SWOT mencakup lingkungan internal dan eksternal perusahaan secara keseluruhan.

\section{Hasil dan Pembahasan}

Dalam menentukan strategi pemasaran diperlukan Analisis SWOT yang bisa menunjukan faktor internal berupa kekuatan dan kelemahan dan faktor eksternal berupa peluang dan ancaman yang dimiliki sebagai berikut:
A. Analisis Internal Factor Analysis Summary (IFAS)
a. kekuatan (Strenghts)
1. Tempat perusahaan bersih.
2. Penyediaan tempat parkir yang luas.
3. Pelayanan yang baik dan handal.
4. Menjalin hubungan dengan pelanggan yang sudah lama kursus.

b. kelemahan(Weaknesses)

1. Belum maksimal dalam menanggapi setiap keluhan pelanggan.

2. Strategi promos yang masih kurang.

3. Adanya karyawan yang datang terlambat.

B. Analisis Internal Factor Eksternal Summary (EFAS)

a. peluang (Opportunities)

\section{Memaksimalkan pemasaran.}


2. Pangsa pasar yang luas.

3. Tinggi rendahnya harga yang ditawarkan

4. Hubungan yang baik dengan pelanggan.

b. Ancaman(Threats)

1. Banyaknya pesaing bisnis.

2. Aturan dari pemerintah.

3. Pendatang baru.

Tabel 1. Analisis SWOT Pada PT. Central International Education

\begin{tabular}{|c|c|c|}
\hline $\mathbf{F}$ & Kekuatan & Kelemahan \\
\hline $\begin{array}{l}\mathbf{I} \\
\mathbf{N} \\
\mathbf{T} \\
\mathbf{E} \\
\mathbf{R} \\
\mathbf{N} \\
\mathbf{A} \\
\mathbf{L}\end{array}$ & $\begin{array}{l}\text { 1. Tempat perusahaan yang } \\
\text { bersih. } \\
\text { 2. Penyediaan tempat parkir yang } \\
\text { luas. } \\
\text { 3. Pelayanan yang baik dan } \\
\text { handal. } \\
\text { 4. Menjalin Hubungan dengan } \\
\text { pelanggan yang sudah lama } \\
\text { kursus. }\end{array}$ & $\begin{array}{l}\text { 1. Belum maksimal dalam } \\
\text { menaggapi keluhan pelanggan. } \\
\text { 2. Strategi promosi yang masih } \\
\text { kurang. } \\
\text { 3. Adanya karyawan yang datang } \\
\text { terlambat. }\end{array}$ \\
\hline $\mathbf{F}$ & Peluang & Ancaman \\
\hline $\begin{array}{l}\mathbf{E} \\
\mathbf{K} \\
\mathbf{S} \\
\mathbf{T} \\
\mathbf{E} \\
\mathbf{R} \\
\mathbf{N} \\
\mathbf{A} \\
\mathbf{L}\end{array}$ & $\begin{array}{l}\text { 1. Memaksimalkan pemasaran. } \\
\text { 2. Pangsa pasar yang luas. } \\
\text { 3. Tinggi rendahnya harga yang } \\
\text { ditawarkan. } \\
\text { 4. Hubungan yang baik dengan } \\
\text { pelanggan. }\end{array}$ & $\begin{array}{l}\text { 1. Banyaknya pesaing bisnis. } \\
\text { 2. Aturan dari pemerintah. } \\
\text { 3. Pendatang baru. }\end{array}$ \\
\hline
\end{tabular}


Tabel 2. IFAS

\begin{tabular}{|c|c|c|c|}
\hline Faktor Strategi Internal & Bobot & Rating & Skor \\
\hline $\begin{array}{l}\text { Kekuatan } \\
\text { 1. Tempat perusahaan yang bersih. } \\
\text { 2. Penyediaan tempat parkir yang luas. } \\
\text { 3. Pelayanan yang baik dan handal. } \\
\text { 4. Menjalin Hubungan dengan } \\
\text { pelanggan yang sudah lama kursus. }\end{array}$ & $\begin{array}{l}0,15 \\
0,10 \\
0,20 \\
0,20\end{array}$ & $\begin{array}{l}7 \\
7 \\
8 \\
8\end{array}$ & $\begin{array}{l}1,05 \\
0,70 \\
1,60 \\
1,60\end{array}$ \\
\hline Sub Total & 0,65 & & 4,95 \\
\hline $\begin{array}{l}\text { Kelemahan } \\
\text { 1. Belum maksimal dalam menaggapi } \\
\text { keluhan pelanggan. } \\
\text { 2. Strategi promosi yang masih kurang. } \\
\text { 3. Adanya karyawan yang datang } \\
\text { terlambat. }\end{array}$ & $\begin{array}{l}0,10 \\
0,10\end{array}$ & $\begin{array}{l}3 \\
2 \\
2\end{array}$ & $\begin{array}{l}0,45 \\
0,20 \\
0,20\end{array}$ \\
\hline Sub Total & $\mathbf{0 , 3 5}$ & & $\mathbf{0 , 8 5}$ \\
\hline Total & 1,00 & & 5,80 \\
\hline
\end{tabular}

Tabel 3. EFAS

\begin{tabular}{|l|c|c|c|}
\hline \multicolumn{1}{|c|}{ Faktor Strategi Eksternal } & Bobot & Rating & Skor \\
\hline $\begin{array}{l}\text { Peluang } \\
\text { 1. Memaksimalkan pemasaran. }\end{array}$ & 0,15 & 8 & 1,20 \\
$\begin{array}{l}\text { 2. Pangsa pasar yang luas. } \\
\text { 3. Tinggi rendahnya harga yang } \\
\text { ditawarkan. }\end{array}$ & 0,10 & 7 & 0,70 \\
4. Hubungan yang baik dengan & 0,20 & 8 & 0,70 \\
$\quad$ pelanggan. & $\mathbf{0 , 5 5}$ & & 1,60 \\
\hline Sub Total & 0,20 & 2 & $\mathbf{4 , 2 0}$ \\
\hline $\begin{array}{l}\text { Ancaman } \\
\text { 1. Banyaknya pesaing bisnis. }\end{array}$ & 0,10 & 2 & 0,40 \\
2. Aturan dari pemerintah. & 0,15 & 2 & 0,30 \\
3. Pendatang baru. & $\mathbf{0 , 4 5}$ & & $\mathbf{0 , 9 0}$ \\
\hline Sub Total & $\mathbf{1 , 0 0}$ & & $\mathbf{5 , 1 0}$ \\
\hline Total &
\end{tabular}

Dengan tersusunnya matrik IFAS dan EFAS tersebut dapat menghasilkan nilai skor pada masing-masing faktor internal dan eksternal sebagai berikut:

- Faktor kekuatan (Strenghts) $=4,95$

- Faktor kelemahan (Weaknesses) $=0,85$ 
- $\quad$ Faktor peluang (Opportunities) $=4,20$

- Faktor Ancaman (Threats) $=0,90$

Berdasarkan analisis SWOT maka diketahui kekuatan lebih tinggi dibandingkan dengan strategi yang lain yaitu 4,95. Dengan demikian alternatif strategi yang paling tepat dengan menggunakan kekuatan untuk memanfaatkan peluang sehingga didapatkan keuntungan yang optimal.

Tabel 4. IFAS dan EFAS

\begin{tabular}{|c|c|c|}
\hline IFAS & $\begin{array}{c}\text { STRENGTH (S) } \\
\text { Kekuatan Internal }\end{array}$ & $\begin{array}{c}\text { WEAKNESS (W) } \\
\text { Kelemahan Internal }\end{array}$ \\
\hline EFAS & 4,95 & 0,85 \\
\hline Opportunities (O) & STRATEGI SO & STRATEGI WO \\
4,20 & $\begin{array}{c}4,95+4,20 \\
=9,15\end{array}$ & $\begin{array}{c}0,85+4,20 \\
=5,05\end{array}$ \\
\hline $\begin{array}{c}\text { THREAT (T) } \\
\text { Ancaman Eksternal }\end{array}$ & STRATEGI ST & STRATEGI WT \\
0,90 & $4,95+0,90$ & $0,85+0,90$ \\
$=5,85$ & 1,75 \\
\hline
\end{tabular}

Tabel 5. Matriks SWOT PT. Central International Education

\begin{tabular}{|c|c|c|}
\hline $\begin{array}{l}\text { Matriks SWOT } \\
\text { PT. Central International } \\
\text { Education }\end{array}$ & $\begin{array}{l}\text { STRENGTH (S) } \\
\text { Kekuatan Internal } \\
\text { 1. Tempat perusahaan } \\
\text { yang bersih. } \\
\text { 2. Penyediaan tempat } \\
\text { parkir yang luas. } \\
\text { 3. Pelayanan yang baik } \\
\text { dan handal. } \\
\text { 4. Menjalin hubungan } \\
\text { dengan pelanggan } \\
\text { yang sudah lama } \\
\text { kursus. }\end{array}$ & $\begin{array}{l}\text { WEAKNESS (W) } \\
\text { Kelemahan Internal } \\
\text { 1. Belum maksimal dalam } \\
\text { menaggapi keluhan } \\
\text { pelanggan. } \\
\text { 2. Strategi promosi yang } \\
\text { masih kurang. } \\
\text { 3. Adanya karyawan } \\
\text { yang datang terlambat. }\end{array}$ \\
\hline & 4,95 & $\mathbf{0 , 8 5}$ \\
\hline 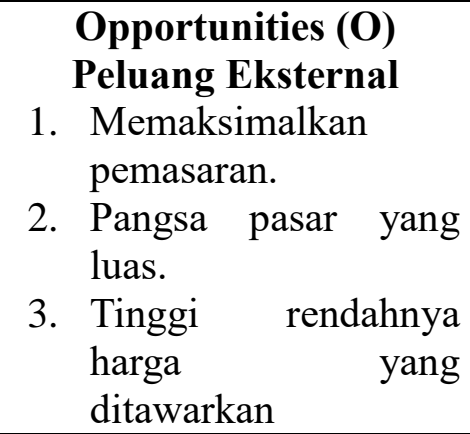 & 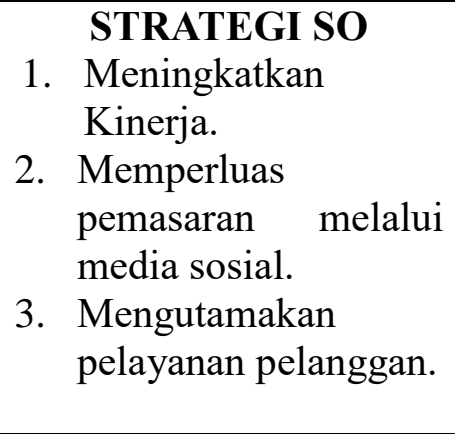 & $\begin{array}{ll} & \text { STRATEGI WO } \\
\text { 1. Meningkatkan kualitas } \\
\text { yang baik dari pesaing. } \\
\text { 2. Perbedaan harga yang } \\
\text { masih wajar dalam } \\
\text { mengatasi pesaing. } \\
\text { 3. Mengutamakan } \\
\text { kedisiplinan. }\end{array}$ \\
\hline
\end{tabular}




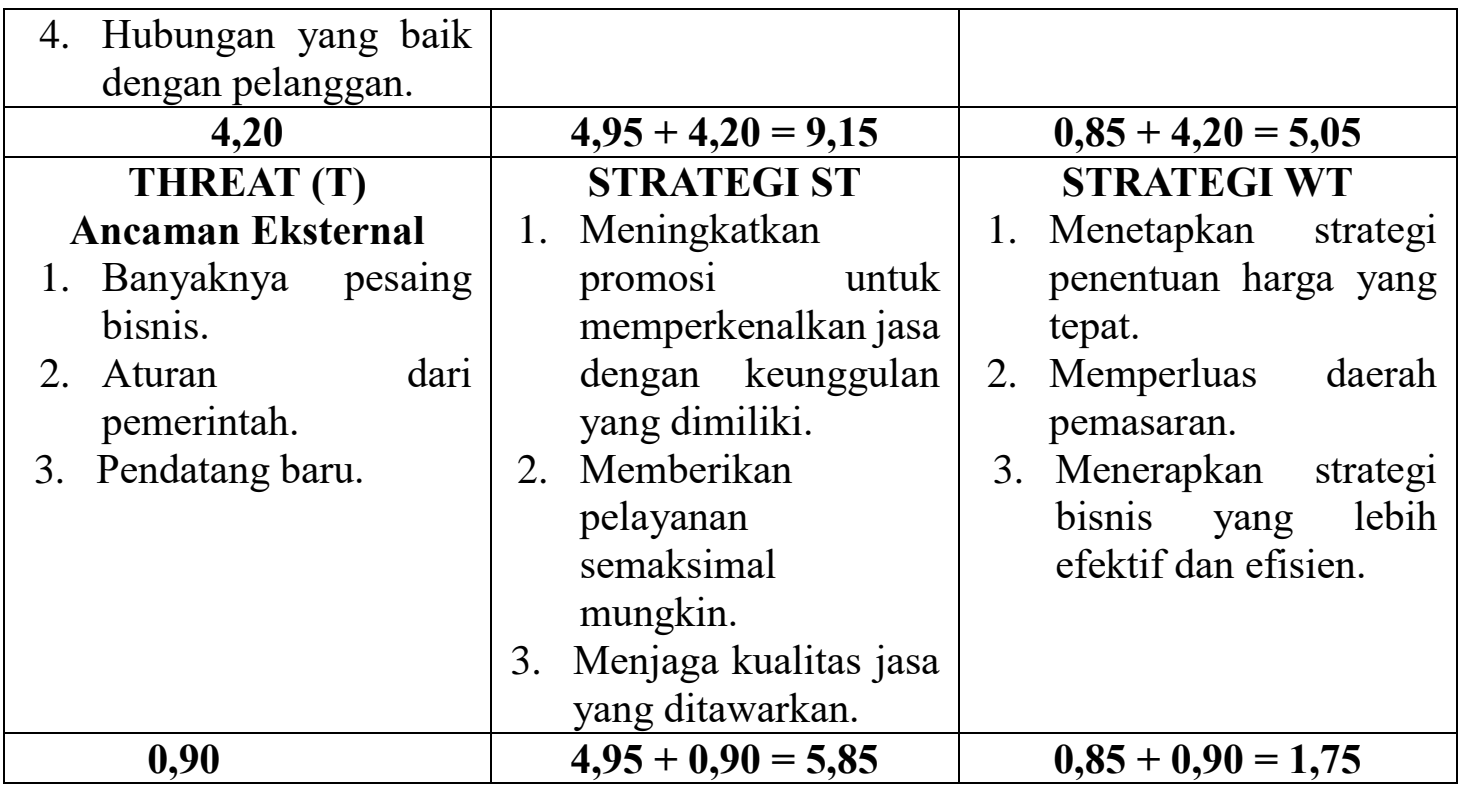

Berdasarkan Analisis SWOT diatas, strategi ini berupa dengan memanfaatkan seluruh kekuatan untuk peluang sebesar-besarnya. Sehingga hal ini memiliki kekuatan dan peluang yang lebih besar dari kelemahan dan ancaman. Kondisi seperti ini memungkinkan setiap kekuatan dan peluang dapat dimaksimalkan dalam peningkatan strategi pemasaran.

Dalam beberapa penemuan yang didapat dari peneliti sebelumnya pemasaran jasa tidak hanya membutuhkan pemasaran eksternal, tetapi juga pemasaran internal diantaranya di dapat dari (Martiman, 2014 ; Multazam, 2013 ; Burhanuddin, 2014). Strategi pemasaran barang dan jasa melalui media iklan sangat diperlukan untuk menginformasikan produk dan jasa perusahaan kepada pasar diantaranya di dapat dari (Martiman, 2014 ; Widyaningrum, 2016). Dan komponen pemasaran yang harus diperhitungkan dengan baik adalah harga produk diantaranya di dapat dari (Martiman, 2014). Sedangkan pemasaran pendidikan mendapatkan pelanggan yang disesuaikan dengan target didapat dari (Elytasari, 2017 ; Andria, dan Sugiharto, 2016). Sedangkan pemasaran jasa pendidikan membutuhkan strategi yang baik agar dapat meningkatkan pengguna pada sebuah lembaga Pendidikan diantaranya di dapat dari (Jahari, dan Syarbini, 2013).

\section{Kesimpulan}

Dapat disimpulkan Matriks SWOT beberapa pengembangan melalui pertimbangan faktor internal dan eksternal yang dapat bermanfaat bagi kemajuan PT. Central International Education. Strategi yang digunakan PT. Central International Education berdasarkan Matriks SWOT yaitu dengan melakukan promosi dan menerapkan strategi pemasaran yang lebih baik menjadi nilai utama untuk bisa menarik pelanggan.

Hasil skor matrik IFAS dan EFAS dapat menghasilkan skor berupa pada masing-masing faktor internal dan eksternal sebagai berikut: (1) Faktor kekuatan (Strenghts) $=4,95$; (2) Faktor kelemahan (Weaknesses) $=0,85$; (3) Faktor peluang (Opportunities) $=4,20$; (4) Faktor Ancaman (Threats) $=0,90 ;$ (5) Berdasarkan analisis SWOT maka diketahui kekuatan lebih tinggi dibandingkan dengan strategi yang lain yaitu 4,95 . 


\section{Referensi}

Andria, dan Sugihartono, Sugiono. (2016). Perencanaan Strategi Pemasaran Dalam Mempertahankan dan Mengembangkan Bisnis. 4(2).

Assauri, Sofjan. (2013). Manajemen Pemasaran. Jakarta: Rajawali Pers.

Burhanuddin, Afid. (2014). Strategi Pemasaran Lembaga Pendidikan.

Elytasari, Suvidian. (2017). Strategi Pemasaran Jasa Pendidikan Untuk Meningkatkan Kepercayaan (Trust). 1(1)

Hasan, Ali. (2013). Marketing Dan Kasus-Kasus Pilihan. Yogyakarta: Caps

Jahari, Jaja. Amirulloh Syarbini. (2013). Manajemen Madrasah (Teori, Strategi dan Implementasi). Bandung: Alfabeta.

Kotler, Philip and Gary, Armstrong. (2012). Prinsip - prinsip Pemasaran. Edisi 13. Jilid 1.

Martiman. (2014). Strategi Pemasaran Barang dan Jasa Perusahaan Melalui Media Iklan. 2(2).

Multazam, Ulil. (2013). Strategi Pemasaran dan Implementasinya Dalam Lembaga Pendidikan. Khoirul, Anam. 1(2): 5.

Rinaldi, Ferry. (2015). Konsep Strategi Pemasaran dan Bauran Pemasaran.

Widyaningrum, Wahyu, Premi. (2016). Peran Media Sosial sebagai Strategi Pemasaran. 2(2).

\section{Copyrights}

Copyright for this article is retained by the author(s), with first publication rights granted to the journal.

This is an open-access article distributed under the terms and conditions of the Creative Commons Attribution license (http://creativecommons.org/licenses/by/4.0/) 